\title{
CLIENT PERCEPTIONS OF THE QUALITY OF VALUATION REPORTS IN AUSTRALIA
}

\author{
GRAEME NEWELL \\ University of Western Sydney
}

\begin{abstract}
A survey of external users of commercial valuation reports was conducted in April 2004 to assess client perceptions of the quality of valuation reports in Australia. This 2004 survey highlighted the further consolidation and improvement in the quality of valuation reports that has occurred over recent years, reflected in the significant increase in the use of DCF analysis and higher levels of client satisfaction in valuations for all commercial property sectors. Continued concerns were raised over the failure to understand the complexities and market position of particular projects and the need for a greater emphasis on the current supply/demand situation.
\end{abstract}

Keywords: Valuation quality, valuation reports, client satisfaction, valuation standards, DCF analysis.

\section{INTRODUCTION}

The issue of professional valuation standards and the quality of valuation reports has been the focus of considerable international attention in recent years. In the UK, in addition to the Royal Institution of Chartered Surveyors (RICS) valuation standards and procedures (RICS, 2003), various industry reports have addressed a range of key issues regarding the quality of the valuation process and valuation reports. These include ensuring greater credibility, reliability and clarity in commercial property valuations (Mallinson Report, 1994), assessing valuers' compliance with the reporting standards of the RICS Red Book (Waters Report, 2000) and ensuring public confidence in the valuation process (Carsberg Report, 2002).

In the US, the Financial Institutions Reform, Recovery and Enforcement Act had major implications for improving appraisal standards (Colwell and Trefzger, 1992; Lahey et al, 1993). This was further enhanced with the introduction of uniform standards of professional appraisal practice by the Appraisal Institute in 1999 (Tosh and Rayburn, 1999). Similarly, in Australia, the Australian Property Institute (API) has been active in developing valuation practice standards (API, 2004) and valuation risk management procedures (API, 2003). These local valuation standards initiatives have been further enhanced by the development of regional valuation 
standards (eg: Europe) (McParland et al, 2002; TEGOVA, 2000) and international valuation standards by the International Valuation Standards Committee (IVSC, 2000).

These professional valuation practice standards developments have been complemented by research into specific aspects relating to valuation standards and practice, including valuation variation (eg: Boyd and Irons, 2002; Crosby, 2000; Crosby et al, 1998; Parker, 1999), valuation uncertainty (eg: Brown et al, 1998; Mallinson and French, 2000) and valuation accuracy (eg: Adair et al, 1996; Newell and Kishore, 1998).

In addition to these developments regarding professional standards and valuation reports, it is particularly important that an assessment is performed as to whether external valuation client needs and expectations are being met concerning the quality of valuation reports. The quality of valuation reports has received considerable attention in the US (Colwell and Trefzger, 1992; Dotzour and Le Compte, 1993; Knitter, 1993, 1994, 1995; Lahey et al, 1993; Rudolph, 1994; Shlaes, 1993; Wilson, 1996) and the UK (Crosby et al, 1997).

In Australia, the issue of the quality of valuation reports has been actively debated by leading valuation practitioners (eg: Rothwell, 1990, 1991, 1994; Smith, 1994), as well as regular property industry surveys conducted over 1989-1998 (Newell and Barrett, 1990; Newell, 1995, 1999, 2004; Newell and Fibbens, 1991). The overall conclusion from these property industry surveys is that the valuation process and the quality of valuation reports have improved considerably over this period (Newell, 1999, 2004). Key factors evident in these quality of valuation report surveys have been the increased use of DCF analysis, increased levels of analytical detail in valuation reports, positive impact of the implementation of the API's valuation standards and the decreased perception of weakness in valuation reports, resulting in improved and better-researched valuations (Newell, 1999).

Given the significant changes in the Australian property industry in recent years, particularly relating to valuation practice (eg: professional indemnity insurance, practice standards), it is particularly important that the quality of valuation reports is assessed on a regular basis. The purpose of this paper is to present the results of a major property industry survey of external users of commercial valuation reports in Australia in 2004 to examine the client perceptions of the quality of valuation reports. The results are compared to previous surveys in 1989, 1994 and 1998 (Newell and Barrett, 1990; Newell, 1995, 1999) to assess the changing perceptions of the quality of valuation reports in Australia over the last fifteen years.

\section{SURVEY METHOD AND USER PROFILE}

A survey designed to obtain information concerning the quality of valuation reports in the Australian property industry was conducted in April 2004. The survey was 
sent to 109 property organisations who were likely major external users of valuation reports, with the contact details of survey participants obtained from Property Investment Research (2003). Participants included property trusts, property syndicates, superannuation funds, insurance companies and property developers ${ }^{1}$.

83 responses were received, with the resulting survey response rate being $76 \%$. Respondents confirmed they were major users of valuation reports, and hence were able to effectively comment on the quality of valuation reports. The main respondents to the survey were managed funds (including listed property trusts, unlisted property trusts and wholesale funds) $(66.3 \%)$, property syndicates $(18.1 \%)$, property developers $(7.2 \%)$ and superannuation funds $(3.6 \%)$.

These survey respondents represented a total property portfolio of $\$ 134.9$ billion, with the total portfolio property types being office $(41.6 \%)$, retail $(34.6 \%)$, industrial $(17.0 \%)$ and other (including hotels, residential, healthcare, childcare, tourism, carparks and entertainment) (6.8\%). The respondents accounted for 1,979 external valuations per annum. The frequency of valuation of individual properties by these external users of valuation reports was largely annually (18\%), every two years $(21 \%)$ and every three years $(35 \%)$. All respondents employed outside valuers to conduct their valuations, with $98 \%$ of valuations conducted by outside valuers.

Full details of the survey respondents are shown in Table 1. For comparative purposes, the survey was consistent with that of the previous 1989, 1994 and 1998 surveys conducted by the author.

Percentage responses were presented for all questions for the survey participants, as well as for the three separate groups of managed funds, property syndicates and property developers. The Spearman rank-order correlation coefficient (Bechtold and Johnson, 1989) was used to assess the rank order agreement between these three separate groups of respondents and between the four quality of valuation reports surveys (1989, 1994, 1998, 2004).

\section{RESULTS AND DISCUSSION}

\section{Use of valuations}

The most important reasons cited for using valuations in these property organisations were for investment decisions $(93 \%$ cited as "important" or “essential"), for legal requirements (93\%) and for lending practices (91\%). In many instances $(33 \%, 35 \%$ and $57 \%$ respectively), valuations were indicated to be essential for the aforesaid reasons.

${ }^{1}$ Property developer details were obtained from the Property Council of Australia (PCA) 2003 membership directory (PCA, 2003). 
$98 \%$ of respondents indicated that valuations were relevant in the investmentrelated decisions of their firms, with $67 \%$ of respondents indicating that valuations were highly relevant in their property investment decision-making. This level of 67\% was above that seen in the previous surveys (eg: 58\% in 1998 survey). Valuations were rated as being more important in the investment-related decisions for property syndicates $(80 \%$ highly relevant) than for managed funds $(62 \%)$ or property developers $(50 \%)$.

\section{Table 1: Quality of valuation reports: survey respondent profile}

Date of survey: April 2004

Number of property organisations surveyed: 109

Number of responses: 83

Survey response rate: $76 \%$

Make-up of survey respondents:

- managed funds (eg: LPTs, unlisted property trusts) $66.3 \%$

- $\quad$ property syndicates

$18.1 \%$

- property developers

$7.2 \%$

- superannuation funds

$3.6 \%$

- insurance companies

$1.2 \%$

- other

Total value of property portfolio: $\$ 134.9$ billion

Make-up of commercial property portfolio:

- office: $\quad \$ 56.1$ billion $(41.6 \%)$

- retail: $\quad \$ 46.7$ billion $(34.6 \%)$

- industrial: $\$ 23.0$ billion $(17.0 \%)$

- other $^{(1)}$ : $\quad \$ 9.1$ billion $(6.8 \%)$

Total number of properties in portfolio: 3,069

Number of external valuations per annum: 1,979

Frequency of external valuations:

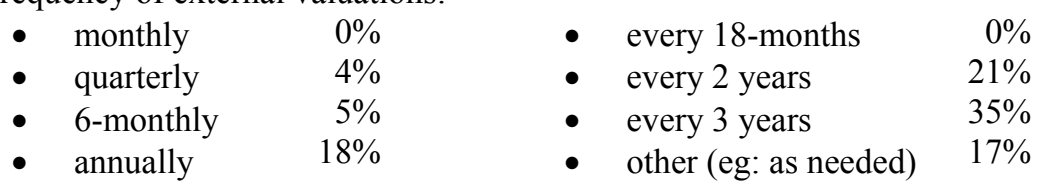

(1) Other includes hotels, residential, healthcare, childcare, tourism, carparks, entertainment, infrastructure

In selecting outside valuers, $76 \%$ of respondents only used valuation firms or individuals that they know from previous experience, being an increase on the $69 \%$ 
of respondents from the previous survey. The requesting of tenders (29\%) was less prevalent than in the previous 1998 survey.

$71 \%$ of respondents believed that there were significant differences in the quality and reliability of valuation reports amongst the valuation firms and valuers available for their use. This level is consistent with the previous survey (1998) and continues the trend from this being a more significant issue in the earlier surveys (1989 and 1994). Managed funds (74\%) considered these differences in quality and reliability to be more significant than property syndicates $(67 \%)$ and property developers (67\%).

\section{Use of DCF analysis}

DCF analysis is now included in $90 \%$ of outside valuations. This continues the trend to increased use of DCF, increasing from $84 \%$ in 1998 and significantly above the levels of $68 \%$ in 1994 and only $36 \%$ in $1989.75 \%$ of respondents require DCF analysis to be included in all valuation reports; an increase on the level of $68 \%$ in the 1998 survey. This trend is consistent with the recent increased use of sophisticated generic valuation software such as DYNA and Cougar (Parker, 2001, 2004 ) and the requirement by many institutional clients to incorporate DCF analysis in valuation reports (Parker, 2004; Parker and Robinson, 2000).

\section{Quality and reliability of valuation reports}

The users of valuation reports indicated that $94 \%$ of valuation reports were at least adequate for their purposes, with this high level of satisfaction consistent with previous surveys. Property syndicates had the highest level of satisfaction with valuation reports ( $99 \%$ considered adequate), with managed funds considering 93\% of valuation reports were adequate.

The level of client satisfaction with valuation report quality was high for each property type; being $97 \%$ for office property, $96 \%$ for retail property and $96 \%$ for industrial property. These levels of satisfaction were above each of the corresponding 1998 levels of $89-92 \%$, as well as being above the client satisfaction levels seen in 1994 and 1989 which were in the $85-90 \%$ range. The level of client satisfaction was marginally higher for property syndicates and property developers than for managed funds.

$80 \%$ of valuation reports were considered to contain sufficient analytical detail to enable a reasoned judgement as to how market value estimates were derived. This was consistent with the previous 1998 survey (Newell, 1999), with managed funds, property syndicates and property developers having consistent views on this level of analytical detail.

$97 \%$ of valuers were considered to be competent in their professional activities, with this level being consistent with all previous surveys over the last fifteen years. 
Managed funds, property syndicates and property developers had consistent views on these high levels of competency by valuers.

Overall, these results on the quality and reliability of valuation reports confirm the continued high standards seen in the previous surveys, with client satisfaction with valuation reports for each of the office, retail and industrial property sectors being higher than that seen in previous surveys over the last fifteen years. Satisfaction with the quality of valuation reports by property syndicates and property developers tended to be marginally higher than for managed funds.

Table 2: Valuation standards and guidelines

\begin{tabular}{|c|c|c|c|c|}
\hline & \multicolumn{4}{|c|}{ Percentage responding "yes" } \\
\hline & 2004 & 1998 & 1994 & 1989 \\
\hline $\begin{array}{l}\text { Monitoring of valuation standards by an } \\
\text { industry body }\end{array}$ & $84 \%$ & $82 \%$ & $90 \%$ & $78 \%$ \\
\hline Standardised valuation guidelines & $81 \%$ & $75 \%$ & $82 \%$ & $73 \%$ \\
\hline Change to current practice & $45 \%$ & $48 \%$ & $69 \%$ & $76 \%$ \\
\hline $\begin{array}{l}\text { Monitoring of valuation standards by a } \\
\text { government regulatory body }\end{array}$ & $20 \%$ & $30 \%$ & $24 \%$ & $10 \%$ \\
\hline
\end{tabular}

\section{Valuation standards and guidelines}

Table 2 presents the perceived need for valuation standards and guidelines over 1989-2004. The monitoring of valuation standards by an industry body (84\%) remains the top priority, as in previous surveys (Newell, 1999). The continued importance of standardised valuation guidelines (81\%) reflects the significant development of guidance notes and practice standards by the API (API, 2004) and the movement towards international valuation standards (IVSC, 2000).

While standardised valuation guidelines are seen as important, further valuation standards were not seen as correcting current shortcomings in valuation reports (see Table 5), being seen as the least favoured (16\%) of the possible suggested solutions for improving valuation report quality. Similarly, changes to current practice (45\%) is at the lowest level of the surveys conducted over the last fifteen years, reflecting positive progress in recent years towards developing suitable valuation standards and guidelines in Australia (API, 2004).

Interestingly, while there is significantly increased usage of DCF analysis in valuation reports, the API is yet to release a DCF practice standard, despite this having been in progress since 1993 (Parker, 2001; Parker and Robinson, 2000). 
However, the need for an API standard on DCF may have been removed by the International Valuation Standards Committee guidance note on DCF.

Table 3: Perceived weaknesses in valuation reports

\begin{tabular}{|c|c|c|c|c|c|c|c|}
\hline \multirow[t]{2}{*}{ Perceived weaknesses } & \multicolumn{3}{|c|}{$\begin{array}{l}\text { Percentage responding } \\
\text { "highly important" }\end{array}$} & \multicolumn{4}{|c|}{$\begin{array}{c}\text { Rank order of } \\
\text { perceived weaknesses }\end{array}$} \\
\hline & 2004 & 1998 & 1994 & 2004 & 1998 & 1994 & 1989 \\
\hline $\begin{array}{l}\text { Failure to understand } \\
\text { complexities and market } \\
\text { position of particular } \\
\text { project }\end{array}$ & $77 \%$ & $68 \%$ & $73 \%$ & 1 & 1 & 2 & 3 \\
\hline $\begin{array}{l}\text { Inadequate market } \\
\text { analysis }\end{array}$ & $71 \%$ & $64 \%$ & $75 \%$ & 2 & 2 & 1 & 1 \\
\hline $\begin{array}{l}\text { Lack of details and } \\
\text { discussion of analytical } \\
\text { aspects }\end{array}$ & $57 \%$ & $49 \%$ & $55 \%$ & 3 & 4 & 4 & 2 \\
\hline $\begin{array}{l}\text { Failure to comment upon } \\
\text { likely market trends }\end{array}$ & $53 \%$ & $52 \%$ & $59 \%$ & 4 & 3 & 3 & 6 \\
\hline $\begin{array}{l}\text { Limited use of } \\
\text { comparables }\end{array}$ & $43 \%$ & $33 \%$ & $36 \%$ & 5 & 6 & 6 & 5 \\
\hline $\begin{array}{l}\text { Limitations on } \\
\text { assumptions and } \\
\text { qualifications of } \\
\text { valuation report }\end{array}$ & $39 \%$ & $45 \%$ & $46 \%$ & 6 & 5 & 5 & 7 \\
\hline $\begin{array}{l}\text { Too much reliance on } \\
\text { historic aspects of } \\
\text { market performance }\end{array}$ & $37 \%$ & $28 \%$ & $35 \%$ & 7 & 7 & 7 & 4 \\
\hline
\end{tabular}

Perceived weaknesses in valuation reports

The users of valuation reports rated seven categories of weaknesses encountered in external valuations of their commercial properties, as shown in Table 3. Failure to understand complexities and market position of particular project (77\%) and inadequate market analysis $(71 \%)$ clearly remain the highest rated of the perceived weaknesses, both being seen to be of more concern than in 1998. Limitations on assumptions $(39 \%)$ and too much reliance on historic aspects of market 
performance $(37 \%)$ were not seen as significant weaknesses, continuing their lesser importance as seen in previous surveys (Newell, 1999).

Table 4: Rank correlations between perceived weaknesses

\begin{tabular}{|c|c|c|c|c|c|}
\hline \multicolumn{6}{|c|}{ Panel A: 1989-2004 } \\
\hline & 2004 & 1998 & 1994 & 1989 & \\
\hline 2004 & 1.00 & & & & \\
\hline 1998 & 0.93 & 1.00 & & & \\
\hline 1994 & 0.89 & 0.96 & 1.00 & & \\
\hline 1989 & 0.64 & 0.43 & 0.50 & 1.00 & \\
\hline \multicolumn{6}{|c|}{ Panel B: Property organisations (2004) } \\
\hline & & $\begin{array}{l}\text { Managed } \\
\text { fund }\end{array}$ & & $\begin{array}{l}\text { Property } \\
\text { syndicate }\end{array}$ & $\begin{array}{l}\text { Property } \\
\text { developer }\end{array}$ \\
\hline \multicolumn{2}{|c|}{ Managed fund } & 1.00 & & & \\
\hline \multicolumn{2}{|c|}{ Property syndicate } & 0.57 & & 1.00 & \\
\hline \multicolumn{2}{|c|}{ Property developer } & 0.64 & & 0.32 & 1.00 \\
\hline
\end{tabular}

As seen in Table 4 (panel A), the 2004 survey results concerning the ranking of perceived weaknesses were more consistent with the 1998 survey (rank correlation $=.93$ ) than with the 1994 and 1989 surveys (rank correlations of .89 and .64 respectively). This confirms the view of recent years being more of a consolidation phase concerning the quality of valuation reports rather than the significant changes seen in the 1989 and 1994 surveys (Newell, 1999). Similarly, Table 4 (panel B) shows that the 2004 views of managed funds and property developers were more closely aligned than those for property syndicates.

\section{Suggested solutions to weaknesses in valuation reports}

The external users of valuation reports also rated a number of possible solutions to the above perceived weaknesses, as shown in Table 5. Greater emphasis on current supply/demand situation (54\%) remains the top rated solution as per the two previous surveys in 1998 (56\%) and 1994 (56\%). Rankings of these four suggested solutions are identical with the previous survey rankings in 1998 (Newell, 1999).

The emphasis given to the solutions of more use of analytical techniques (47\%) and the need for more detailed workings to be provided (37\%) was consistent with the 1998 survey. This clearly reflects the increased use of DCF and increase in analytical detail in valuation reports in recent years, as evidenced in the earlier results in this paper. Importantly, the need for more valuation standards $(16 \%)$ was significantly below that seen in the previous surveys, reflecting the substantial 
progress by the API in recent years regarding professional valuation practice standards and guidelines (API, 2004).

Table 5: Suggested solutions to perceived valuation weaknesses

\begin{tabular}{|c|c|c|c|c|c|c|c|}
\hline \multirow[t]{2}{*}{ Suggested solutions } & \multicolumn{3}{|c|}{$\begin{array}{c}\text { Percentage } \\
\text { responding } \\
\text { "highly important" }\end{array}$} & \multicolumn{4}{|c|}{$\begin{array}{c}\text { Rank order of } \\
\text { suggested solutions }\end{array}$} \\
\hline & 2004 & 1998 & 1994 & 2004 & 1998 & 1994 & 1989 \\
\hline $\begin{array}{l}\text { Greater emphasis on current } \\
\text { supply/demand situation }\end{array}$ & $54 \%$ & $56 \%$ & $56 \%$ & 1 & 1 & 1 & 4 \\
\hline $\begin{array}{l}\text { More use of analytical } \\
\text { techniques (eg: DCF) }\end{array}$ & $47 \%$ & $44 \%$ & $56 \%$ & 2 & 2 & 3 & 3 \\
\hline $\begin{array}{l}\text { Need for more detailed } \\
\text { workings to be provided }\end{array}$ & $37 \%$ & $40 \%$ & $56 \%$ & 3 & 3 & 2 & 2 \\
\hline $\begin{array}{l}\text { Need for more valuation } \\
\text { standards }\end{array}$ & $16 \%$ & $33 \%$ & $35 \%$ & 4 & 4 & 4 & 1 \\
\hline
\end{tabular}

As seen in Table 6 (panel A), the 2004 survey results concerning the ranking of suggested solutions were more consistent with the 1998 survey (rank correlation = 1.00) than with the 1994 and 1989 surveys. This further confirms 2004 being seen as more concerned with consolidation rather than with significant change regarding the quality of valuation reports. Table 6 (panel B) shows that the views of managed funds, property syndicates and property developers were consistent regarding suggested solutions for valuation report weaknesses.

Table 6: Rank correlations between suggested solutions

\begin{tabular}{|c|c|c|c|c|c|c|}
\hline \multicolumn{7}{|c|}{ Panel A: 1989-2004 } \\
\hline & 2004 & 1998 & 1994 & & 1989 & \\
\hline 2004 & 1.00 & & & & & \\
\hline 1998 & 1.00 & 1.00 & & & & \\
\hline 1994 & 0.80 & 0.80 & 1.00 & & & \\
\hline 1989 & -1.00 & -1.00 & -0.80 & & 1.00 & \\
\hline \multicolumn{7}{|c|}{ Panel B: Property organisations (2004) } \\
\hline & & $\begin{array}{l}\text { Managed } \\
\text { fund }\end{array}$ & & $\begin{array}{l}\text { Property } \\
\text { syndicate }\end{array}$ & & $\begin{array}{l}\text { Property } \\
\text { developer }\end{array}$ \\
\hline \multicolumn{2}{|c|}{ Managed fund } & 1.00 & & & & \\
\hline \multicolumn{2}{|c|}{ Property syndicate } & 0.80 & & 1.00 & & \\
\hline \multicolumn{2}{|c|}{ Property developer } & 0.80 & & 1.00 & & 1.00 \\
\hline
\end{tabular}




\section{General comments}

In addition to the above specific analyses, the general comments provided by survey respondents showed some useful insights into the client perceptions of the quality of valuation reports. These general comments were in the key areas of:

- the quality of the valuation report depends on the quality of the briefing given to the valuer

- $\quad$ significant improvement in the quality of valuation reports in the last five years (eg: use of DYNA etc.)

- too many disclaimers to cover potential liability issues

- low valuations from fear of liability issues

- too much generic and dated information

- lack of support for contentions with quality information

- poor knowledge of financial markets and other asset classes

- need for standard requirements, similar to accounting standards. For example, in the revised Australian Accounting Standards effective from January 2005, international asset valuation standards apply to property plant and equipment (AASB116), leases (AASB117), impairment of assets (AASB136) and investment property (AASB140), replacing the currently adopted AASB1041 (Preston, 2004).

Whilst these general comments are similar to those in the previous 1998 survey (Newell, 1999), increased focus in this 2004 survey is seen in the concerns over liability issues on valuation report quality. This reflects major recent concerns over professional indemnity insurance and risk management in valuation practice.

\section{CONCLUSIONS}

This 2004 survey has clearly shown that further consolidation and improvement in the quality of valuation reports in Australia has occurred over the last five years.

Key highlights for the quality of valuation reports in Australia over the last five years have been:

- $\quad$ increased relevance of valuations in property investment decisionmaking

- $\quad$ significant increase in the use of DCF analysis

- higher levels of client satisfaction in valuations for all commercial property sectors

- $\quad$ continued concerns over weakness of failure to understand complexities and market position of particular project 
- $\quad$ continued need for main solution of greater emphasis on the current supply/demand situation,

with these issues ensuring that the client and valuer are more fully aware and better informed of the expectations and requirements of valuation report content and standards.

Overall, this 2004 survey regarding the quality of valuation reports has provided a very positive view amongst clients regarding their perceptions of the quality of valuation reports in Australia. Ongoing issues that will need to be carefully monitored include increased concerns over liability issues on valuation report quality and the impact of the introduction of the international accounting standards (IAS) in 2005 (Burgess, 2004). These IAS procedures have potential implications for the valuation of commercial properties in Australia, particularly concerning the consistent reporting of net tangible asset value and the frequency of valuations.

\section{REFERENCES}

Adair, A. et al. (1996). An analysis of valuation variation in the UK commercial property market: Hager and Lord revisited. Journal of Property Valuation and Investment 14(5): 34-47.

Australian Property Institute. (2004). Professional Practice 2004. Australian Property Institute: Canberra.

Australian Property Institute. (2003). Risk Management Module. Australian Property Institute: Canberra (www.nat.propertyinstitute.com.au).

Bechtold, B. and Johnson, R. (1989). Statistics for Business and Economics. PWSKent: Boston.

Boyd, T. and Irons, J. (2002). Valuation variance and negligence: the importance of reasonable care. Pacific Rim Property Research Journal 8(2): 107-126.

Brown, G. et al. (1998). Valuation uncertainty and the Mallinson Report. Journal of Property Research 15(1): 1-13.

Burgess, K. (2004). Value's new meaning. Commercial Property Gazette (July): 2223.

Carsberg Report. (2002). Property Valuation. Royal Institution of Chartered Surveyors: London. 
Colwell, P. and Trefzger, J. (1992). Impact of regulation on appraisal quality. The Appraisal Journal (July): 428-429.

Crosby, N. (2000). Valuation accuracy, variation, and bias in the context of standards and expectations. Journal of Property Investment and Finance 18(2): 130161.

Crosby, N., Lavers, A. and Murdoch, J. (1998). Property valuation variation and the "margin of error" in the UK. Journal of Property Research 15(4): 305-330.

Crosby, N., Newell, G., Matysiak, G., French, N. and Rodney, B. (1997). Client perception of property investment valuation reports in the UK. Journal of Property Research 14(1): 27-48.

Dotzour, M. and Le Compte, R. (1993). Lender perceptions of appraisal quality after FIRREA. The Appraisal Journal (April): 227-233.

IVSC. (2000). International Valuation Standards. (2000). International Valuation Standards Committee.

Knitter, R. (1993). What clients want from appraisal reports. The Appraisal Journal (April): 272-276.

Knitter, R. (1994). 1993 survey of appraisal clients. The Appraisal Journal (January):113-117.

Knitter, R. (1995). 1994 survey of appraisal clients. The Appraisal Journal (April): 213-219.

Lahey, K., Ott, D. and Lahey, V. (1993). Survey of the effects of state certification on appraisers. The Appraisal Journal (July): 405-413.

Mallinson, M. and French, N. (2000). Uncertainty in property valuation. Journal of Property Investment and Finance 18(1): 13-32.

Mallinson Report. (1994). Commercial Property Valuation. Royal Institution of Chartered Surveyors: London.

McParland, C., Adair, A. and McGreal, S. (2002). Valuation standards: a comparison of four European countries. Journal of Property Investment and Finance 20(2): 127-141.

Newell, G. (1995). The quality of valuation reports. The Valuer and Land Economist 33(5): 358-360.

Pacific Rim Property Research Journal, Vol 10, No 4 
Newell, G. (1999). The quality of valuation reports in Australia: 1998. Australian Property Journal 35(7): 605-608.

Newell, G. (2004). Assessing professional valuation practice standards. Australian Property Journal (in press).

Newell, G. and Barrett, V. (1990). The quality of valuation reports. The Valuer 31(2): 96-98.

Newell, G. and Fibbens, M. (1991). Professional valuation practice standards in NSW. The Valuer 31(4): 382-385.

Newell, G. and Kishore, R. (1998). Are valuations an effective proxy for property sales? The Valuer and Land Economist 31(4): 150-153.

Parker, D. (1999). A note on valuation accuracy: an Australian case-study. Journal of Property Investment and Finance 17(4): 401-411.

Parker, D. (2001). Observations on trends in institutional property valuations. Australian Property Journal 36(5): 426-429.

Parker, D. (2004). DCF1 - how does the property fund management industry do discounted cash flow? Australian Property Journal 38(1): 21-27.

Parker, D. and Robinson, J. (2000). A brief history of the Australian DCF practice standard. Journal of Property Investment and Finance 18(2): 196-211.

Preston, G. (2004). President's message. API News 10(5): 1-2.

Property Council of Australia. (2003). 2003 People in Property. PCA: Sydney.

Property Investment Research. (2003). Australian Property Funds Industry Survey 2003. PIR: Melbourne.

Rothwell, G. (1990). Valuation standards. The Valuer 31(4): 224-228.

Rothwell, G. (1991). Valuations: the new perspective. The Valuer 31(7): 474-477.

Rothwell, G. (1994). Valuation methodology and market needs. The Valuer and Land Economist 33(1): 18-20.

RICS. (2003). RICS Appraisal and Valuation Standards. Royal Institution of Chartered Surveyors: London. 
Rudolph, P. (1994). Will bad appraisers drive out good? The Appraisal Journal (July): 363-366.

Shlaes, J. (1993). The quality appraisal report. The Appraisal Journal (Oct): 483488.

Smith, B. (1994). Client expectations of valuers and valuations. The Valuer and Land Economist 33(2): 131-132.

TEGOVA. (2000). European Valuation Standards 2000. Estates Gazette: London.

Tosh, D. and Rayburn, W. (1999). Uniform Standards of Professional Appraisal Practice. Dearborn: Chicago.

Wilson, D. (1996). Are appraisal reports logical fallacies? The Appraisal Journal (April): 129-133.

Waters Report. (2000). Valuers' Compliance with the Reporting Standards of the RICS Red Book. Royal Institution of Chartered Surveyors: London. 